\title{
Cryptic diversity in smooth-shelled mussels on Southern Ocean islands: connectivity, hybridisation and a marine invasion
}

\author{
Małgorzata Zbawicka', Jonathan P. A. Gardner ${ }^{2}$ and Roman Wenne ${ }^{1 *}$ (D
}

\begin{abstract}
Background: Large numbers of endemic species inhabit subantarctic continental coasts and islands that are characterised by highly variable environmental conditions. Southern hemisphere populations of taxa that are morphologically similar to northern counterparts have traditionally been considered to be extensions of such Northern hemisphere taxa, and may not exhibit differentiation amongst geographically isolated populations in the Southern Ocean. Smooth-shelled blue mussels of the genus Mytilus that exhibit an anti-tropical distribution are a model group to study phylogeography, speciation and hybridisation in the sea, and contribute to the theory and practice of marine biosecurity.
\end{abstract}

Methods: We used a single nucleotide polymorphism (SNPs) panel that has the ability to accurately identify reference Northern and Southern hemisphere Mytilus taxa to test for evolutionary differentiation amongst native Southern Ocean island populations.

Results: Native mussels from the Falkland Islands and the Kerguelen Islands exhibited greatest affinity to native M. platensis d'Orbigny 1846 from the Atlantic coast of South America. The major Southern Ocean current flow from west to east is likely to explain the spreading of $M$. platensis to remote offshore islands, as adults via the process of rafting or perhaps directly as larvae. SNPs variation revealed that mussels from Tasmania were native and clearly differentiated from all other blue mussel groups in the Southern and Northern hemispheres. The native mussels M. planulatus from Tasmania and from mainland New Zealand (NZ), and tentatively M. aoteanus from the two NZ Southern Ocean offshore island groups (the Auckland Islands and Campbell Island), formed a distinct M. galloprovincialis-like Southern hemisphere group with closest affinity to Northern hemisphere M. galloprovincialis from the Mediterranean Sea. In all cases, the SNPs revealed evidence of hybridisation between two or more distinct taxa. The invasive Northern hemisphere M. galloprovincialis was identified only in Tasmania, amongst native mussels of a distinct Australian M. planulatus lineage.

Conclusion: Overall, our results reveal that Southern hemisphere island mussels have mixed genome ancestry and are native, not introduced by human activities. The preservation of distinct evolutionary lineages of Southern hemisphere species needs to be an ongoing focus of conservation efforts, given that population sizes on some of the remote offshore oceanic islands will be small and may be more easily adversely affected by invasion and subsequent hybridisation and introgression than larger populations elsewhere.

Keywords: Mytilus, Southern Ocean, SNP genotyping, Introgression, Hybridisation, Falkland Islands, Kerguelen Islands, Tasmania, New Zealand

\footnotetext{
* Correspondence: rwenne@iopan.gda.pl

${ }^{1}$ Institute of Oceanology, Polish Academy of Sciences, Powstańców

Warszawy 55, 81-712 Sopot, Poland

Full list of author information is available at the end of the article
}

(c) The Author(s). 2019 Open Access This article is distributed under the terms of the Creative Commons Attribution 4.0 International License (http://creativecommons.org/licenses/by/4.0/), which permits unrestricted use, distribution, and reproduction in any medium, provided you give appropriate credit to the original author(s) and the source, provide a link to the Creative Commons license, and indicate if changes were made. The Creative Commons Public Domain Dedication waiver (http://creativecommons.org/publicdomain/zero/1.0/) applies to the data made available in this article, unless otherwise stated. 


\section{Background}

Subantarctic continental coasts and remote island intertidal zones are characterised by intermediate levels of biodiversity and large numbers of endemic species [1]. Morphologically similar Southern hemisphere populations have traditionally been considered to be extensions of Northern hemisphere populations and taxa, or undifferentiated populations in the Southern Ocean. Increasingly, over the last two or three centuries, anthropogenic activities have, however, resulted in the blurring of patterns of natural distributions, even in remote locations, often with profound ecological, economic and social costs [2-4]. Because of increased human activities, including maritime traffic, geographic ranges of endemic marine species may be extended, their populations mixed via hybridisation or endangered by invasions of alien species [5]. In addition, ocean rafting is increasingly recognised as an important natural method of range expansion of some marine taxa $[6,7]$ and there is evidence that increased storm activity resulting from global warming may help to break down the geographic isolation of regions such as Antarctica [8]. Whilst the natural distributions of some marine species may be relatively easy to identify in the absence of human-mediated accidental or deliberate movements, for many other species this may not be the case. Understanding the natural patterns of species distributions in the Southern Ocean have long been a challenge, given the scale of the endeavour, but this challenge is increasingly becoming more difficult due to recent mixing of species and the blurring of species' natural distributions.

For some species, including smooth-shelled blue mussels of the genus Mytilus, the translocation of individuals may result in extensive erosion of species differences (genotypic and phenotypic) and the disruption of natural patterns of distribution, because such mussels are known to hybridise and backcross extensively in almost all cases where two or more species co-exist [9-11]. Invasive blue mussels, in particular the Northern hemisphere Mediterranean mussel, Mytilus galloprovincialis, occur in many regions of the world (refer to [4, 12, 13]) and in some regions, such as the Pacific coast of the United States, have out-competed and largely replaced the native species [14-16]. The mechanistic basis of this invasion success is presently unknown, but evidence points to the greater thermal tolerance of M. galloprovincialis over its congenerics [17].

Smooth-shelled blue mussels of the genus Mytilus are a model group that provide excellent opportunities to examine phylogeography, evolution, speciation and hybridisation in the sea and to test the theory and practice of marine biosecurity. Blue mussels are naturally widely occurring, with an anti-tropical distribution, in all areas except polar regions $[12,18]$. They are remarkably tolerant of environmental variation [19], and are ecosystem engineers $[20,21]$. In many parts of the world mussels are an important source of protein, both in terms of wild harvest and aquaculture production [22-24]. Over the last 50 years or so, a better global understanding of the phylogeography, taxonomy and systematics of smoothshelled blue mussels of the genus Mytilus has been achieved with a range of genetic marker types, from allozymes (protein variation) [25-30], through mitochondrial DNA (mtDNA) sequencing and restriction fragment length polymorphisms (RFLPs) [31-42], to nuclear DNA markers [43-48], such as microsatellites [49-55] and, most recently, single nucleotide polymorphisms (SNPs) [56-61]. The development and application of each new generation of molecular marker type has provided new insight into the phylogeography and the biosecurity threat of blue mussels in a global perspective. The recent development of SNPs for mussels of the genus Mytilus [62] and their application to mussels from New Zealand [4], Chile [13] and Argentina [63] has revealed profound and consistent genetic differences amongst multiple Southern hemisphere evolutionary lineages. The SNPs data also confirm, in all of these regions, the existence of invasive Northern hemisphere $M$. galloprovincialis and/or the hybridisation and introgression of non-native genes into the native lineage.

Whilst the phylogeography and taxonomy of native Southern hemisphere blue mussels is becoming clearer following the application of the SNP markers, most of the work to date has focussed on collections from coastal sites on major land masses. One topic that has not been investigated in any depth is the question of the phylogeography of blue mussels on remote offshore islands in the southern Atlantic, Indian and Pacific oceans. These islands are very small land masses in a very large expanse of ocean that effectively encircles (below latitude $55^{\circ} \mathrm{S}$ ) the Southern hemisphere, and which may provide some degree of connectivity for marine species with pelagic larval durations that are long enough to move from one stepping stone island to another [64-66] and/or may be capable of long distance movement via a process such as rafting on kelp $[7,67]$. To date, the only SNPs investigation of New Zealand (NZ) Southern Ocean blue mussel island populations has highlighted the existence of unique island lineages and also introgression of non-native genes into island mussel populations [4]. Despite their remoteness, the NZ Southern Ocean islands do not have a refuge from invading mussels, and may, perhaps, act as a stepping stone for the introduction of invasive mussels, or at least for mussels with introgressed genes, to establish on Antarctic shores $[68,69]$. These findings highlight the urgent need to describe and better understand the biogeography of blue mussels (and other marine taxa) found on the small and isolated islands of the Southern Ocean. 
The aim of the present research was to determine the genetic differentiation, phylogeography and the taxonomic status of blue mussels from Southern Ocean islands and to investigate the extent, if any, of introduction of non-native blue mussels and their hybridisation and introgression with native species. We used SNPs that differentiate amongst mussel populations from the Southern hemisphere, including Argentina (M. platensis), Chile ( $M$. chilensis) and New Zealand (Southern hemisphere M. galloprovincialis-like) and also amongst reference Northern hemisphere taxa (M. edulis, M. galloprovincialis, M. trossulus) $[4,13,63]$. We assayed SNP variation in mussels from the Falkland Islands (South Atlantic Ocean), Kerguelen Islands (South Indian Ocean) and from Tasmania (South Pacific Ocean). We also tested for the occurrence of hybridisation and introgression between native populations and invasive blue mussels. This works contributes to ongoing efforts to better understand the natural distributions, patterns of genetic connectivity across large ocean in scales and evolutionary affinities of blue mussels in the Southern hemisphere.

\section{Methods}

\section{Sample collection and SNP genotyping}

Mytilus spp. samples that consisted of 77 individuals of mixed ages and sizes (5-50 $\mathrm{mm}$ shell length) were collected from six localities at the Falkland (Malvinas) Islands (2 sites), the Kerguelen Islands (3 sites: I3B, BO100av and IS in Gérard et al. [70]) and Tasmania (1 site) between 2002 and 2015 (Fig. 1, Table 1). Whole specimens or tissue samples were stored in $96 \%$ ethanol. DNA was isolated from the mantle tissue using a modified CTAB method [71]. Thirteen previously described reference samples including 354 specimens were included: $M$. edulis from the Atlantic coast of USA and Northern Ireland, UK; Northern hemisphere $M$. galloprovincialis from the Atlantic coast of Spain and the Mediterranean Sea; native Southern hemisphere $M$. galloprovincialis-like mussels from mainland New Zealand and from Southern Ocean offshore islands; $M$. trossulus from Atlantic Canada (Halifax, Nova Scotia) and Pacific Canada (Vancouver, British Columbia); M. chilensis from Chiloé, Chile and Ushuaia, Strait of Magellan, southern Argentina); and $M$. platensis from Comodoro Rivadavia on the Atlantic coast of Argentina [4, 13, 62, 63, 72]. To identify amongst populations and to identify instances of hybridisation, 79 SNPs that differentiate amongst species were used [4, 62, 63]. Samples were genotyped using the Sequenom MassARRAY iPLEX genotyping platform [73].

\section{Data analysis}

\section{Genetic diversity}

Populations were analysed for allele frequencies, proportion of polymorphic SNPs $\left(P_{O}\right)$ genetic diversity, observed $\left(H_{O}\right)$ and expected $\left(H_{E}\right)$ heterozygosity, genetic differentiation (pairwise $F_{\mathrm{ST}}$ ), and inbreeding coefficient $\left(F_{\mathrm{IS}}\right)$ using Arlequin v. 3.5.1.2 [74]. Departures from Hardy-Weinberg equilibrium (HWE) were tested by exact test, and significance was determined by Markov chain Monte Carlo simulations. The false discovery rate (FDR-BY) was used to correct significance $(P)$ values after multiple testing $[75,76]$.

\section{Population genetic differentiation and structure}

$F_{\mathrm{ST}}$ distance measures in the Newick format, obtained in POPTREEW [77], were used to construct a neighbourjoining (NJ) tree illustrating the genetic relationships amongst populations. Correspondence analysis (CA; Benzécri [78]), implemented in GENETIX [79] was used to visualise genetic substructure amongst populations and individuals. Population structure was inferred by determining the number of clusters (groups) observed without prior knowledge of sampling location. Bayesian clustering using STRUCTURE v. 2.3.4 software with the model assuming admixture, ignoring population affiliation and allowing for the correlation of allele frequencies amongst clusters was used to infer groups $[80,81]$. The most appropriate number of genetic clusters was determined by a diagram-based comparison of log-likelihoods for values of $K$ ranging from one to the study number of populations plus one. At least five runs were used for each $K$ value, following the method described by Evanno et al. [82]. The length of burn-in period was 50,000 and the number of MCMC cycles after burn-in was 100,000 iterations each. Genetic assignment was obtained by using two methods. Following the STRUCTURE analysis, a threshold value of $\mathrm{q}=0.8$ was used to assign individuals to clusters. Individuals with q-values from 0.2 to 0.8 were considered to be potentially admixed [83].

Genetic assignment of individuals to population of origin was carried out using frequency criteria on the basis of multilocus genotype data [84] and the Bayesian method of Rannala \& Mountain [85] implemented in GeneClass2.0 [86]. Individuals were considered to be correctly assigned to their location of origin if the assignment probability to that group was higher than any other assignment probability to any other group.

\section{Hybridisation and introgression}

The likelihood of hybridisation and introgression was assessed using the software NewHybrids v1 [87]. NewHybrids was used to estimate the posterior probability that individuals from the Falkland Islands, the Kerguelen Islands, Tasmania and from the NZ Southern Ocean islands fell into one of the genotypic categories: M. platensis, M. chilensis, Northern hemisphere M. galloprovincialis, Southern 


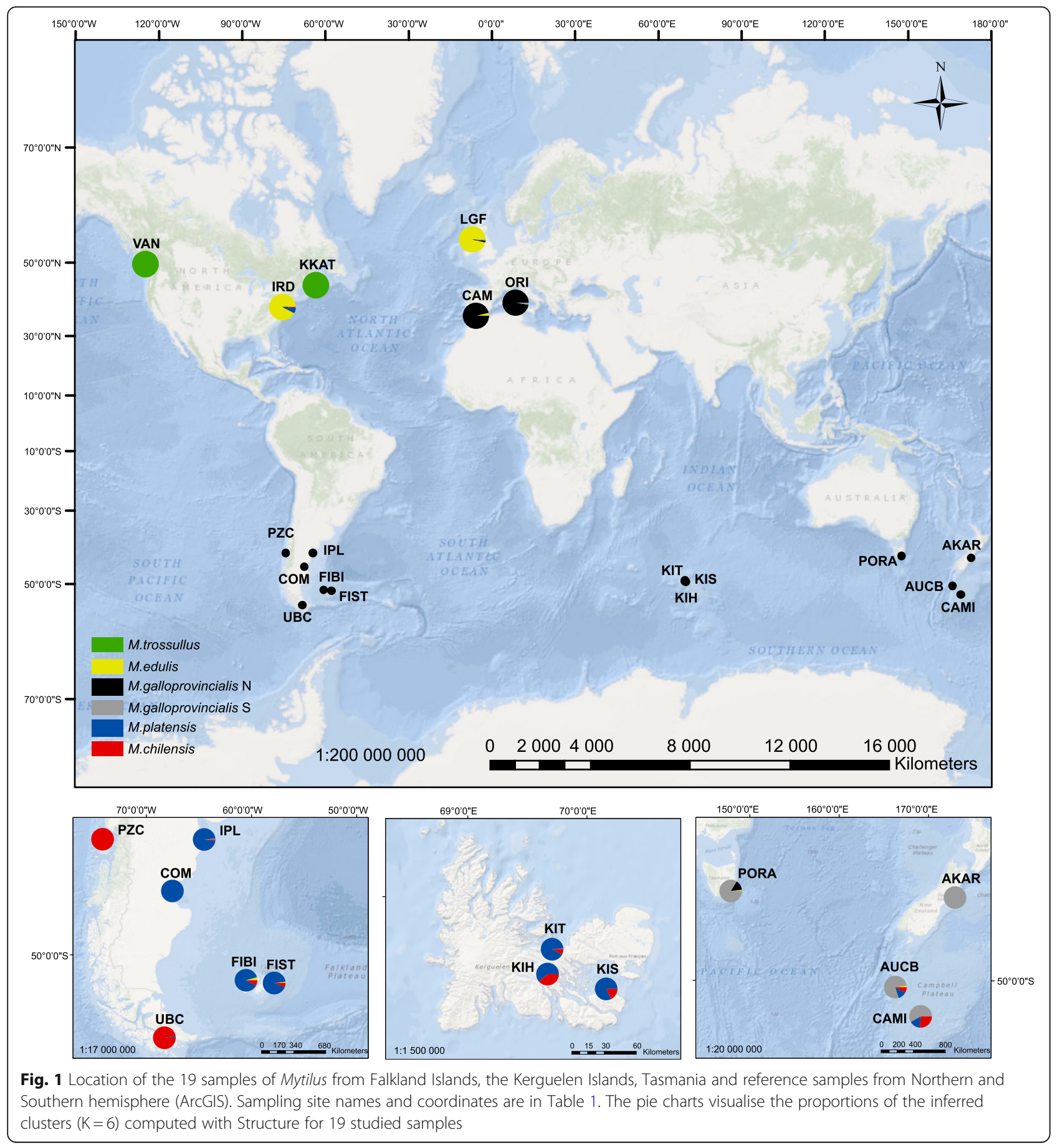

hemisphere M. galloprovincialis-like, F1 hybrids, F2 hybrids and backcrosses.

\section{Results}

\section{Genetic diversity}

Eight samples from four regions (the Falkland Islands, the Kerguelen Islands, Tasmania, and the NZ Southern Ocean islands) encompassing the South Atlantic Ocean, the South Indian Ocean and the South Pacific Ocean were analysed for SNP variation, along with reference populations from both the Northern and Southern hemispheres. Of 79 SNPs assayed, 53 were used for analysis (Table 1, Additional file 2: Table S1 and Additional file 3: Table S2).

The proportion of polymorphic SNPs $\left(P_{o}\right)$ for the eight Southern hemisphere island populations ranged from 
Table 1 Localisation, number and genetic parameters of the 19 samples of Mytilus mussels

\begin{tabular}{|c|c|c|c|c|c|c|c|c|c|c|c|c|c|c|}
\hline Name & Localisation & Country & Water area & No. of indivivuals & $\% P_{o}$ & $H_{0}$ & $H_{E}$ & $\begin{array}{l}\text { Av. gene } \\
\text { diversity over } \\
\text { loci }\end{array}$ & $\begin{array}{l}\text { Av. no. of } \\
\text { pairwise } \\
\text { differences within } \\
\text { population }\end{array}$ & $F_{I S}$ & MAF & Coordinate & Coordinate & $\begin{array}{l}\text { Sampling } \\
\text { year }\end{array}$ \\
\hline FIBI & Bense Island, Falkland & Great Britain & Atlantic & 9 & 30.189 & 0.229 & 0.313 & 0.070 & 3.850 & 0.171 & 0.059 & $51^{\circ} 31^{\prime} 34.02^{\prime \prime} \mathrm{S}$ & $60^{\circ} 31^{\prime} 38.86^{\prime \prime} \mathrm{W}$ & 2002 \\
\hline FIST & Stanley Wharf, Falkland & Great Britain & Atlantic & 13 & 26.415 & 0.365 & 0.392 & 0.103 & 5.357 & 0.054 & 0.072 & $51^{\circ} 41^{\prime 21.63 " \mathrm{~S}}$ & $57^{\circ} 51^{\prime} 2.66^{\prime \prime} \mathrm{W}$ & 2003 \\
\hline $\mathrm{KIH}$ & Henri Bossiere Fjord, Kerguelen & France & Indian Ocean & 12 & 32.075 & 0.41 & 0.386 & 0.127 & 6.475 & -0.072 & 0.091 & $49^{\circ} 24^{\prime} 28^{\prime \prime} \mathrm{S}$ & $69^{\circ} 40^{\prime} 06^{\prime \prime} \mathrm{E}$ & 2003 \\
\hline KIS & Ile Suhm, Kerguelen & France & Indian Ocean & 11 & 30.189 & 0.389 & 0.409 & 0.117 & 6.208 & 0.020 & 0.086 & $49^{\circ} 30^{\prime} 18^{\prime \prime} \mathrm{S}$ & $70^{\circ} 09^{\prime} 38^{\prime \prime} \mathrm{E}$ & 2003 \\
\hline KIT & Ilot des Trois Bergers, Kerguelen & France & Indian Ocean & 12 & 33.962 & 0.289 & 0.331 & 0.109 & 5.678 & 0.109 & 0.073 & $49^{\circ} 17^{\prime} 17^{\prime \prime} \mathrm{S}$ & $69^{\circ} 42^{\prime} 23^{\prime \prime} \mathrm{E}$ & 2003 \\
\hline AKAR* & Akaroa South Island & $\begin{array}{l}\text { New } \\
\text { Zealand } \\
\text { New }\end{array}$ & Pacific & 30 & 28.302 & 0.142 & 0.15 & 0.040 & 2.122 & 0.027 & 0.094 & $43^{\circ} 40^{\prime} 19^{\prime \prime} \mathrm{S}$ & $172^{\circ} 57^{\prime} 54^{\prime \prime} \mathrm{E}$ & 2008 \\
\hline AUCB* & Offshore Island & $\begin{array}{l}\text { Zealand } \\
\text { New }\end{array}$ & Pacific & 20 & 39.623 & 0.192 & 0.255 & 0.077 & 4.301 & 0.131 & 0.077 & $50^{\circ} 29^{\prime} 23^{\prime \prime} \mathrm{S}$ & $166^{\circ} 16^{\prime} 46^{\prime \prime} \mathrm{E}$ & 2004 \\
\hline CAMI* & Offshore Island & Zealand & Pacific & 29 & 39.623 & 0.244 & 0.279 & 0.093 & 4.898 & 0.029 & 0.063 & $52^{\circ} 31^{\prime} 36^{\prime \prime} \mathrm{S}$ & $169^{\circ} 650^{\prime \prime} \mathrm{E}$ & 2004 \\
\hline PORA & Tasmania & Australia & Pacific & 20 & 39.623 & 0.181 & 0.234 & 0.082 & 4.209 & 0.124 & 0.066 & $43^{\circ} 8^{\prime} 29^{\prime \prime} \mathrm{S}$ & $147^{\circ} 51^{\prime} 23^{\prime \prime} \mathrm{E}$ & 2009 \\
\hline $\mathrm{PZC}^{*}$ & Chiloe & Chile & Pacific & 30 & 37.736 & 0.299 & 0.332 & 0.127 & 6.464 & 0.083 & 0.074 & $42^{\circ} 24^{\prime} 0.54^{\prime \prime S}$ & $74^{\circ} 10^{\prime} 48.49^{\prime \prime} \mathrm{W}$ & 2012 \\
\hline UBC* & Ushuaia & Argentina & Atlantic & 28 & 32.075 & 0.331 & 0.344 & 0.111 & 5.650 & 0.021 & 0.080 & $54^{\circ} 48^{\prime} 19.09^{\prime \prime S}$ & $68^{\circ} 17^{\prime} 34.31 " \mathrm{~W}$ & 2013 \\
\hline $\mathrm{COM}^{*}$ & Comodoro Rivadavia & Argentina & Atlantic & 35 & 33.962 & 0.229 & 0.269 & 0.086 & 4.549 & 0.122 & 0.070 & $45^{\circ} 56^{\prime} 00^{\prime \prime S}$ & $67^{\circ} 32^{\prime} 0.00^{\prime \prime} \mathrm{W}$ & 2014 \\
\hline IPL* & Isla de los Pajaros & Argentina & Atlantic & 29 & 32.075 & 0.306 & 0.309 & 0.091 & 4.909 & -0.026 & 0.117 & $42^{\circ} 25^{\prime} 16.60^{\prime \prime S}$ & $64^{\circ} 30^{\prime} 58.99^{\prime \prime} \mathrm{W}$ & 2013 \\
\hline IRD* & Indian River, Delaware & $\begin{array}{l}\text { USA } \\
\text { North }\end{array}$ & Atlantic & 25 & 41.509 & 0.243 & 0.268 & 0.111 & 5.755 & 0.084 & 0.099 & $38^{\circ} 36^{\prime 2} 27.36^{\prime \prime} \mathrm{N}$ & $75^{\circ} 3^{\prime} 37.079^{\prime \prime W}$ & 2012 \\
\hline $\mathrm{CAM}^{*}$ & Camarinal & Spain & Atlantic & 26 & 45.283 & 0.326 & 0.351 & 0.152 & 8.057 & 0.051 & 0.066 & $36^{\circ} 4^{\prime} 48.01 " \mathrm{~N}$ & $5^{\circ} 47^{\prime} 58.00^{\prime \prime} \mathrm{W}$ & 2004 \\
\hline ORI* & Oristano & Italy & Mediterranean & 29 & 47.17 & 0.295 & 0.314 & 0.139 & 7.348 & 0.029 & 0.074 & $39^{\circ} 47^{\prime} 59.88^{\prime \prime} \mathrm{N}$ & $8^{\circ} 31^{\prime} 9.72 " \mathrm{E}$ & 2006 \\
\hline VAN* & Vancouver & Canada & Pacific & 19 & 35.849 & 0.267 & 0.292 & 0.089 & 4.603 & -0.030 & 0.072 & $49^{\circ} 40^{\prime} 19^{\prime \prime} \mathrm{N}$ & $124^{\circ} 56^{\prime} 34^{\prime \prime} \mathrm{W}$ & 2006 \\
\hline KKAT* & Halifax & Canada & Atlantic & 28 & 58.491 & 0.206 & 0.246 & 0.131 & 6.933 & 0.121 & 0.103 & $44^{\circ} 30^{\prime} 33.79^{\prime \prime} \mathrm{N}$ & $63^{\circ} 29^{2} 24.91 " \mathrm{~W}$ & 2003 \\
\hline
\end{tabular}

* - reference samples, $P_{O}, \%$ of polymorphic loci; $F_{I S}$, inbreeding coefficient; $H_{O}$, observed heterozygosity; $H_{E}$, expected heterozygosity; values with $\mathrm{P}<0.05$ after Benjamini-Yekutieli correction are marked in bold

26.4 to $39.6 \%$. Observed heterozygosity $\left(H_{o}\right)$ for 53 loci amongst most samples was lower than expected $\left(H_{E}\right)$. The samples from the Kerguelen Islands were characterised by high observed heterozygosity values and gene diversity values, compared to the samples from the NZ Southern Ocean islands (Table 1). Only nine of 1007 test results involving five different loci were not in HardyWeinberg equilibrium (HWE) after correction for multiple testing. $F_{\mathrm{ST}}$ values at individual SNP loci ranged from 0.028 to 1.000 , and 26 SNPs had $F_{\mathrm{ST}}$ values significantly different from zero (Additional file 2: Table S1).

\section{Population genetic differentiation and structure}

In total, 164 of 171 pairwise comparisons of $F_{\mathrm{ST}}$ values were significantly different from zero after FDR-BY correction. Four of the seven non-significant values involved samples from the Kerguelen Islands (Additional file 4: Table S3). Greatest differentiation was observed between the New Zealand M. galloprovincialis-like and the Canadian M. trossulus samples.

The Falkland Islands and Kerguelen Islands samples showed greatest similarity to reference $M$. platensis from Comodoro, Argentina $\left(F_{\mathrm{ST}}=0.04-0.15\right)$. Despite this, the Falkland Islands and Kerguelen Islands mussels were significantly differentiated, based on $F_{\mathrm{ST}}$ values. The Tasmanian sample showed greatest similarity to the NZ mainland population of Akaroa (Southern hemisphere M. galloprovincialis-like) and then to the two Northern hemisphere M. galloprovincialis populations.

The NJ tree based on the $F_{\mathrm{ST}}$ distance matrix revealed six main clades: (1) M. trossulus, (2) Southern hemisphere M. galloprovincialis-like mussels, (3) Northern hemisphere M. galloprovincialis, (4) M. edulis, (5) M. chilensis from Chile and (6) M. platensis from Argentina, including mussels from the Falkland Islands and Kerguelen Islands (Fig. 2).

Correspondence analyses (CA) carried out on 17 samples (i.e., excluding $M$. trossulus, for higher resolution of results) resolved five groups: the reference $M$. edulis, Southern hemisphere M. galloprovincialis-like, Northern hemisphere $M$. galloprovincialis, the NZ Southern Ocean islands, and M. platensis with $M$. chilensis including the Falkland Islands and Kerguelen Islands samples (Fig. 3a). The first two axes explained $66 \%$ of the total variation. Axis 1 (44\% of variation) revealed a separation between M. galloprovincialis, M. edulis and M. platensis from $M$. chilensis. Axis 2 (22\% of variation) revealed a separation between $M$. galloprovincialis populations from the Northern and Southern hemispheres and $M$. platensis from $M$. chilensis. CA carried out for individuals (Fig. 3b) revealed that mussels from the Kerguelen Islands exhibited overlap with the $M$. platensis and $M$. chilensis individuals, whereas mussels from the Falkland Islands exhibited far more overlap with M. platensis than with $M$. chilensis. Tasmanian mussels clustered together between Southern and Northern hemisphere M. galloprovincialis. NZ Southern Ocean island individuals clustered between Southern hemisphere M. galloprovincialis-like mussels from mainland NZ and M. chilensis. CA of the Chile, Argentina, Falkland Islands and Kerguelen Islands mussels (Fig. 3c) revealed clear separation of samples based on geography, with the Falkland Islands and Kerguelen Islands mussels showing greater similarity to $M$. platensis than to $M$. chilensis. The same CA based on individuals (Fig. 3d) revealed limited overlap of the Kerguelen Islands mussels with the M. chilensis, and no 


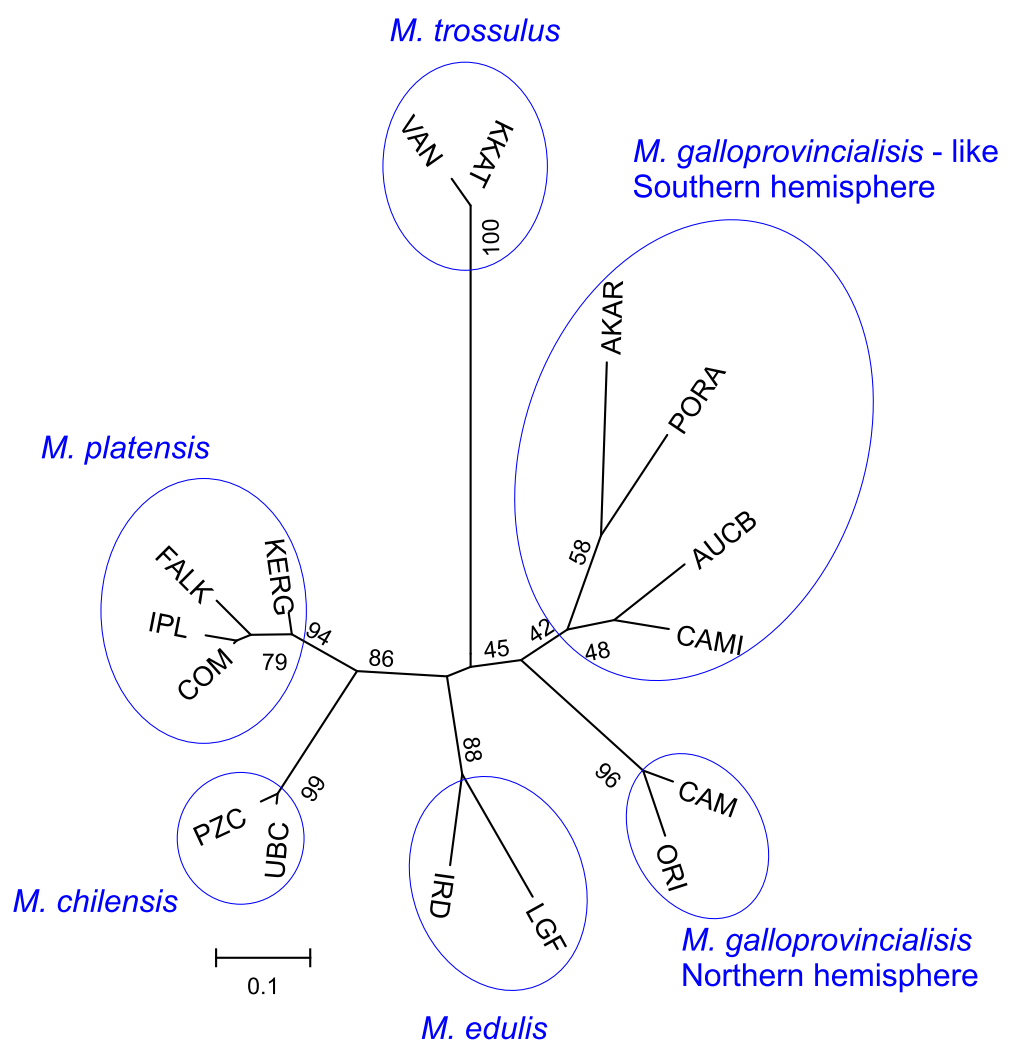

Fig. 2 Neighbour-joining tree of Falkland Islands, the Kerguelen Islands, Tasmania and the reference Mytilus taxa. NJ tree shows genetic relationship between 16 Mytilus spp. samples based on the $F$ distance measures obtained with POPTREEW and visualised with MEGA version 6

overlap of the Falkland Islands mussels with the M. chilensis. Considerable overlap was revealed for both the Falkland Islands and Kerguelen Islands mussels with $M$. platensis. Whilst axis 1 (66.8\% of the total variation) explained the differentiation of $M$. chilensis from all other mussels, axis 2 (13.1\%) contributed to explaining the separation amongst the Falkland Islands, Kerguelen Islands and $M$. platensis samples, although there was still some overlap amongst these individuals.

STRUCTURE analysis revealed the presence of six main clusters, although the largest increase in $\Delta \mathrm{K}$ was obtained for $K=2$, and then $K=3$ and $K=6$. For $K=2$ only $M$. trossulus was separated from all other Mytilus taxa, whilst $K=3$ clusters corresponded to $M$. trossulus, $M$. edulis together with $M$. galloprovincialis, and all other groups. Further subdivision was suggested due to the high value of $\Delta \mathrm{K}$ for $K=6$, where samples from Argentina (M. platensis), Chile and southern Argentina (M. chilensis), and New Zealand and Australia-Tasmania (Southern hemisphere M. galloprovincialis-like) were assigned to distinct clusters (Fig. 1, Additional file 1: Figure S1).

In STRUCTURE for $K=6$ the reference individuals (M. edulis, M. trossulus, M. galloprovincialis, M. chilensis and $M$. platensis) were assigned to their original samples (taxa) with q values $>0.8$. In contrast, individual assignments for Falkland Islands, Kerguelen Islands and Tasmania samples, which were influenced by introgression, were frequently intermediate with as much as 23, 25 and 20\%, respectively, of samples showing q values between 0.2 and 0.8 . Most individuals from the Falkland Islands and the Kerguelen Islands were assigned to $M$. platensis, whilst other individuals were considered potentially admixed (M. chilensis $\times$ M. platensis). Three individuals from the Kerguelen Islands population of Henri Bossiere Fjord clustered with $M$. chilensis. Individuals with genome admixture were assigned to two clusters, M. chilensis and M. platensis. In total, $75 \%$ of individuals from Tasmania were assigned to the Southern hemisphere $M$. galloprovincialis-like cluster, one individual (5\%) was identified as non-native Northern hemisphere M. galloprovincialis, and the remaining individuals from Tasmania were identified as admixed, being assigned to Northern hemisphere M. galloprovincialis $\times$ Southern hemisphere $M$. galloprovincialislike. The NZ Southern Ocean island mussels exhibited very high levels of admixture: 13 (27\%) individuals were assigned to Southern hemisphere M. galloprovincialis-like with $\mathrm{q}$ values $>0.8$, whereas all other individuals were assigned to two clusters, mainly to Southern hemisphere 


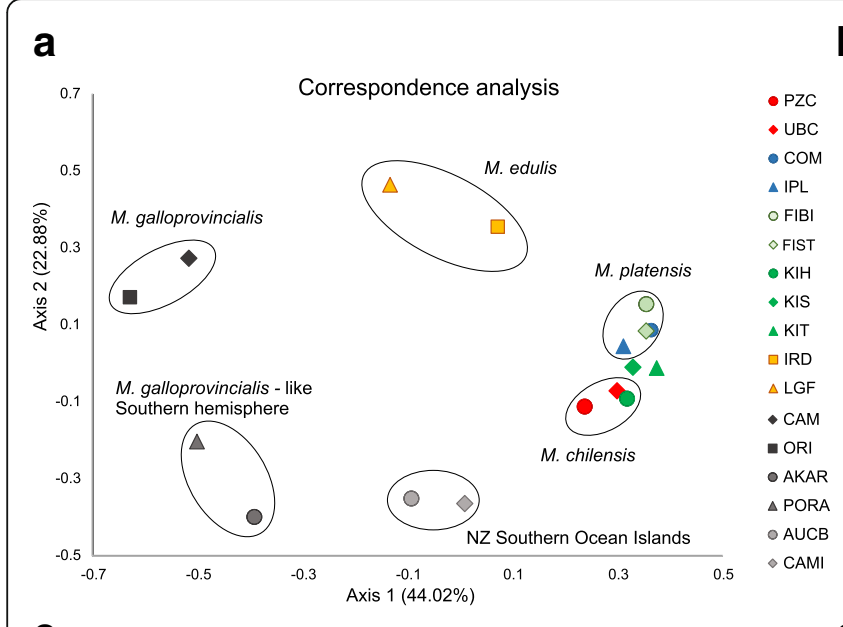

C

b

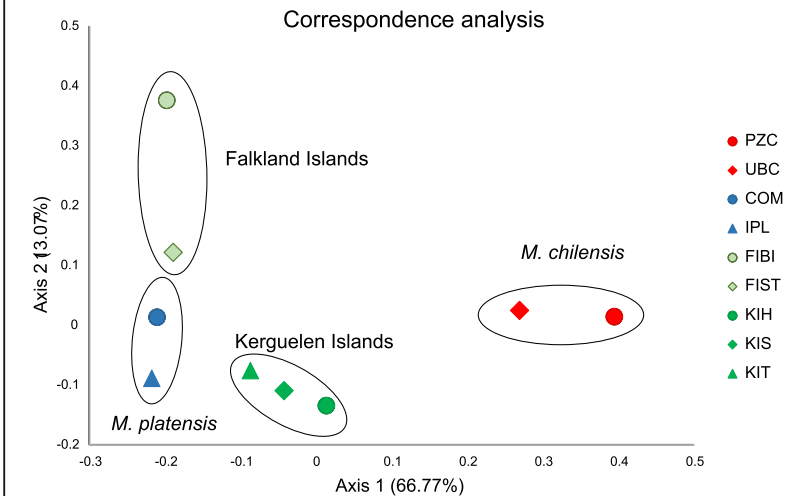

d
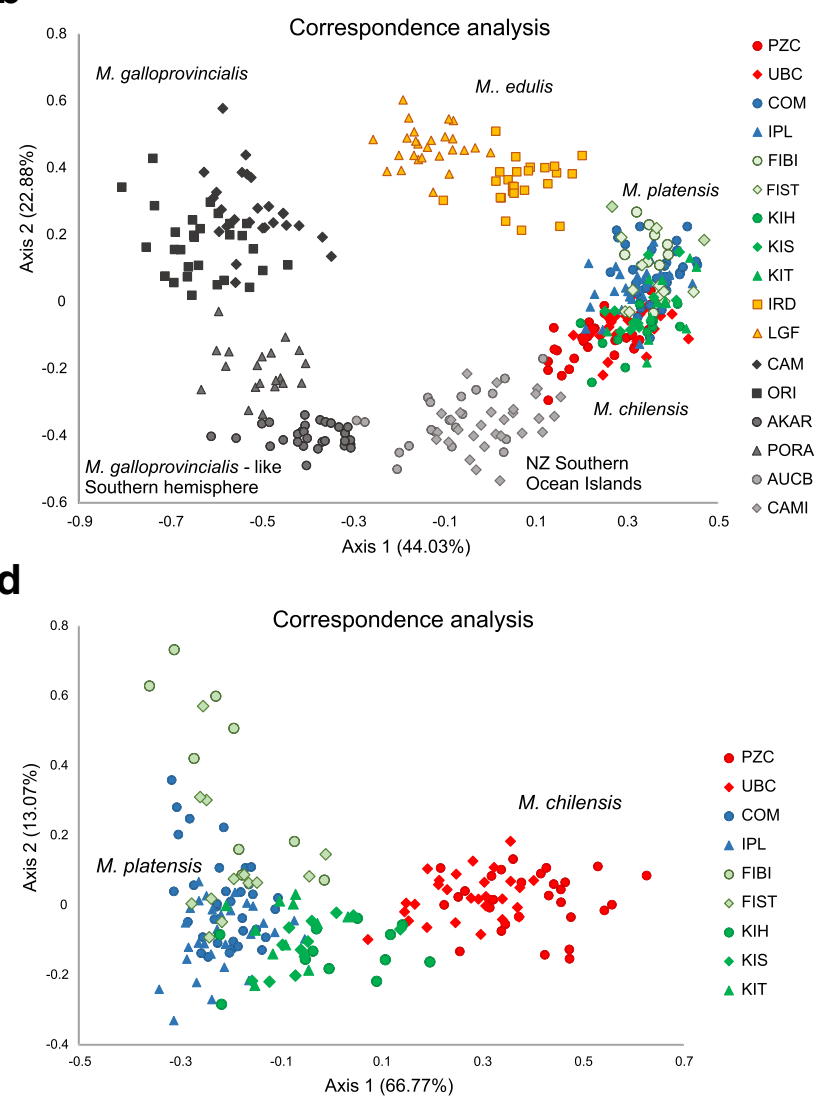

Fig. 3 The first two axes of the correspondence analysis (CA) computed from the SNP data on sixteen samples from Falkland Islands, the Kerguelen Islands, Tasmania and reference populations of M. edulis, M. galloprovincialis and M. chilensis and M. platensis from America, Europe and New Zealand (a and $\mathbf{b}$ ). CA of the Chile, Argentina, Falkland Islands and Kerguelen Islands mussels (c and $\mathbf{d}$ ). Each dot is sample (a and $\mathbf{c}$ ) or an individual (b and $\mathbf{d}$ )

M. galloprovincialis-like $\times$ M. chilensis but also to Southern hemisphere M. galloprovincialis-like $\times$ M. platensis.

In total, $94 \%$ of individuals were correctly assigned to their location of origin using GeneClass2. Potentially admixed individuals from the Falkland Islands and the Kerguelen Islands were assigned to their original location or to the Argentinian sample (M. platensis) from Isla de los Pajaros (IPL). Likewise, most of the potentially admixed Tasmanian and NZ Southern Ocean islands individuals were assigned to their original location, or to mainland New Zealand (Additional file 5: Table S4 assignments).

\section{Hybridisation and introgression}

In total, $14 \%$ of individuals from the Falkland Islands and $28 \%$ of individuals from the Kerguelen Islands were identified as F2 hybrids (M. chilensis $\times$ M. platensis). F1 hybrids and backcrosses were not detected in the Falkland Islands or Kerguelen Islands samples. In contrast, amongst mussels from the NZ Southern Ocean,
45\% of Auckland Islands individuals and 90\% of Campbell Island individuals were influenced by hybridisation and introgression. They were also identified as F2 hybrids (mainly Southern hemisphere M. galloprovincialislike $\times M$. chilensis or Southern hemisphere $M$. galloprovincialis-like $\times$ M. platensis). Hybrid and backcross individuals were not detected in the Tasmanian population.

\section{Discussion \\ Phylogeography}

Building on the recent descriptions of native blue mussels from Southern hemisphere locations, such as New Zealand [4], Chile [13] and Argentina [63], we show that mussels from the Southern Ocean islands are native and very different from the three recognised Northern hemisphere reference taxa of M. edulis, M. galloprovincialis and $M$. trossulus.

Native mussels from the Falkland Islands and the Kerguelen Islands showed greatest affinity to native 
mussels from the Atlantic coast of Argentina, that is, to M. platensis d'Orbigny, 1846 [63]. The separation of this group of South Atlantic Ocean and South Indian Ocean mussels is very well supported by the SNPs analyses that clearly differentiate it from all other blue mussel groups in the Northern and Southern hemispheres. Previously, Lamy [88] had recognised three species in this part of the world, based on shell morphological differences, including $M$. chilensis from Chile, $M$. platensis from Argentina and $M$. desolationis from the Kerguelen Islands. Subsequently, these mussels have been described as being $M$. edulis-like (that is, most similar to Northern hemisphere $M$. edulis) by a number of authors, based on a range of genetic markers and also on shell morphometric analyses, e.g. [26, 89, 90]. Here, a reasonably small panel of SNPs can correctly assign $91 \%$ of the Falkland Islands and also 91\% of the Kerguelen Islands mussels ( $M$. platensis-like) to their sampling group (native range), this being the highest value of correct assignment observed for all Southern hemisphere island blue mussel populations. In a broader perspective, when compared using the SNP markers to reference mussels from the Northern hemisphere, the $M$. platensis group shows greatest affinity to M. edulis, then to M. galloprovincialis and then to $M$. trossulus. At a broad level of interpretation, the SNPs-based results are consistent with earlier suggestions that M. platensis is "M. edulis-like", but because of the high degree of species-specific definition across the SNPs panel, a quantifiable genetic difference exists amongst the four groups to allow us to differentiate M. platensis from M. chilensis and all Northern hemisphere species as a separate evolutionary lineage.

As assessed by SNP variation, the native mussels from Tasmania, from mainland New Zealand (NZ) and from the two groups of NZ Southern Ocean offshore islands (the Auckland Islands and the Campbell Islands) formed a group distinct from all other groups. This group has variously been called $M$. planulatus in Australia (Lamarck [91]), M. aoteanus or M. edulis aoteanus in New Zealand (Powell [92]), and Southern hemisphere M. galloprovincialis [93, 94]. McDonald et al. [26] had previously noted that mussels from Australia and NZ were similar in allozyme allele frequencies and shell morphology to Northern hemisphere M. galloprovincialis, and went on to note that such Southern hemisphere mussels are likely to be native, rather than introduced. The SNPs markers identify this group as being quite distinct from other Southern hemisphere mussels from both coasts of South America and from the other remote oceanic islands. Within this group, the mainland $\mathrm{NZ}$ population (Akaroa in the South Island) and the Australian sample from Port Arthur (Tasmania) called tentatively $M$. planulatus show greatest affinity and are differentiated from the NZ Southern Ocean remote island samples called tentatively $M$. aoteanus, with greater (e.g., the CA) or lesser (e.g., bootstrap values on the NJ tree) support. The Tasmanian, Campbell Island and Auckland Islands mussels can be assigned correctly to their sampling locations with 90, 83 and 80\% accuracy. When compared to reference samples from the Northern hemisphere the mussels from this 'Australasian' group show greatest affinity to M. galloprovincialis, with the Tasmanian mussels showing greater affinity than the NZ mussels.

\section{Genetic connectivity and physical flow}

The overall patterns of Mytilus Southern hemisphere island phylogeography as assessed using SNPs are remarkably consistent with the geography of sample locations, and with proximity to the major landmasses and their native mussels, as now reported using SNPs. This strongly suggests that natural long distance dispersal events have played a key role in the establishment of mussel populations on remote oceanic islands through the Southern Ocean.

Direction of ocean current in the Southern Ocean is from west to east, with a strong circular pattern of current at approx. $50-55^{\circ} \mathrm{S}$ that connects, to a greater or lesser extent, all land masses in the Southern hemisphere and many of the remote oceanic islands [95]. It is therefore not surprising that the native mussels of the Falkland Islands, or even of the Kerguelen Islands, show greatest affinity to the native mussels of Argentina (M. platensis), and that the different regions of the Southern hemisphere (Pacific coast of South America, Atlantic coast of South America, Australasia) are characterised by their own mussel lineages. As an aside, it is both interesting and surprising that South Africa alone as a major landmass in the Southern hemisphere was not colonised naturally by blue mussels (Mytilus sp. is a recent invader in South Africa $[96,97])$. This might be explained by the fact that southern Africa is in warm-temperate waters, north of the major Southern hemisphere west-to-east flow of coldtemperate and cold current that connects all other landmasses to the south [98].

Physical flow, and therefore connectivity in terms of pelagic larval dispersal (mussels typically have a 28 day pelagic larval duration which may be extended by cooler (oceanic) water temperatures - Bayne [99]), and/or rafting of juvenile or adult mussels on kelp [6, 100], will promote connectivity between regions. In contrast, major features such oceanic fronts may act as barriers to gene flow (connectivity) between regions, and may give rise to separate biogeographic faunas, both in shallow and deep waters (e.g. [98, 101-103] and references therein). Understanding the apparent conflicting effects of isolation caused by features such as oceanic fronts, which may give rise to different evolutionary lineages, and the promotion of gene flow via indirect mechanisms 
such as rafting, which may give rise to population-topopulation connectivity or promote natural hybridisation between differentiated lineages, is a major challenge for an improved understanding of the marine biogeography of the Southern hemisphere. For example, oceanic fronts may act as barriers to gene flow over long (evolutionary) timescales, but may be semi-permeable (subject to jetting and incursions) at shorter timescales and in different places, e.g. $[1,104]$. Indeed, there is increasing evidence in the Southern hemisphere of both cryptic speciation (different evolutionary lineages) of many groups of marine organisms, including crustaceans, echinoderms, molluscs, macroalgae and nematodes [1] and of long distance transport of kelps and kelp-associated organisms $[8,105]$. Our results for Southern hemisphere blue mussels support this increasing body of biogeographic work and point to the importance of isolating features that may give rise to separate evolutionary lineages, and also the role that natural hybridisation may play in speciation on remote oceanic islands when connectivity is promoted, perhaps by a natural process such as rafting.

Because SNPs are co-dominant nuclear markers they are a powerful tool for the investigation of hybridisation and introgression that may occur, either naturally when two or more species/taxa share natural distributions $[72,106]$ or when one species (most often, Northern hemisphere $M$. galloprovincialis) has been introduced by human activity into the range of another, native species $[4,13,16,63]$. Some SNP alleles that are characteristic of Northern hemisphere $M$. trossulus and $M$. edulis, but not of $M$. galloprovincialis, were observed in Southern hemisphere island populations, often at high frequency (e.g. BM101A, BM115B, BM12A, BM17B and BM61A - Additional file 3: Table S2). This situation has previously been reported for mussels from the NZ Southern Ocean islands [4]. SNP loci containing these alleles did not depart from Hardy-Weinberg Equilibrium, suggesting that these may be ancestral polymorphisms and that these loci may be evolutionarily conserved. However, a single specimen of Northern hemisphere M. galloprovincialis has been observed in Tasmania.

Most individuals identified as being potentially admixed individuals were indeed influenced by hybridisation and introgression. However, the extent of hybridisation and introgression varied from location to location. Although no F1 hybrids or backcross mussels were detected at either the Falkland Islands or the Kerguelen Islands, the Falkland Islands mussels showed a lower percentage of F2 mussels (M. platensis $\times$ M. chilensis) than did the Kerguelen Islands mussels (14\% vs $28 \%$ ), despite the latter being $\sim 7800 \mathrm{~km}$ to the east, that is, further from the presumptive source of mainland South American populations. Putative hybrids of M. chilensis $\times$ Northern hemisphere M. galloprovincialis and also of $M$. chilensis $\times M$. trossulus in several southern Chile mussel populations were reported with a single DNA marker (PCR-RFLP of Me 15-16) by Larraín et al. [107]. The restriction site of the RFLP-PCR Me15-16 assay $[18,108,109]$ corresponds to SNP BM151A in this study. Allele $\mathrm{T}$ was found only in reference samples from Chile (M. chilensis) and New Zealand (M. galloprovincialis-like from Southern hemisphere), whereas allele G was found in the remaining locations (Northern hemisphere M. edulis, M. galloprovincialis, M. trossulus and Argentinian M. platensis). Thus, SNP BM151A cannot be treated as a diagnostic marker for Southern Hemisphere mussels.

Consistent with earlier work [4], but employing a new analytical approach, we identified high levels of hybridisation and introgression amongst mussels of the Auckland Islands (45\%) and Campbell Island (90\%), two remote $\mathrm{NZ}$ island groups separated by $\sim 280 \mathrm{~km}$ in the Southern Ocean. All such mussels were F2 hybrids (no F1 hybrids or backcrosses were identified) of Southern hemisphere M. galloprovincialis-like mussels and either $M$. chilensis or $M$. platensis. In contrast, one invasive Northern hemisphere M. galloprovincialis individual was identified from Port Arthur (Tasmania, Australia) amongst native Southern hemisphere M. galloprovincialis-like mussels. Hybrids and backcrosses were not identified. Interpreting the Tasmanian results with published data need to be carried out with care, given that earlier studies have used different markers and samples from different locations, e.g. [18, 93, 94, 110-113].

\section{Conclusions}

Native mussels from the Falkland Islands and the Kerguelen Islands showed greatest affinity to native mussels from the Atlantic coast of South America, that is, to $M$. platensis. The native mussels $M$. planulatus. From Tasmania and from mainland New Zealand (NZ), and tentative $M$. aoteanus from the two NZ Southern Ocean offshore islands (the Auckland Islands and Campbell Island) formed a M. galloprovincialis-like Southern hemisphere group. Invasive Northern hemisphere M. galloprovincialis was identified from Port Arthur (Tasmania, Australia). The application of SNPs markers to smooth-shelled blue mussel phylogeography and biosecurity illustrates the complexity of identifying invading individuals and/or introgressed non-native genes when population sizes may be small and rates of invasion or introgression are very low, and/or when the landscape of invasion is complex, with a limited number of sites (e.g., ports and marinas) experiencing invasion and most sites not. Such results highlight the need for ongoing monitoring of ports and marinas as points of entry for non-native species. It is hoped that a panel of SNPs can now be converted into diagnostic markers and used to rapidly and cheaply assay mussels and provide same-day results to managers who may need to understand the implications of bioinvasion and subsequent 
ecological and economic impacts on native mussels and the ecosystems in which they live. The preservation of distinct evolutionary lineages (or Southern hemisphere species as is increasingly becoming apparent) needs to be an ongoing focus of conservation efforts, given that population sizes on some of the remote offshore oceanic islands will be small and may be more easily adversely effected by invasion and subsequent hybridisation and introgression than larger populations elsewhere.

\section{Additional files}

Additional file 1: Figure S1. Structure plots for the 19 studied samples $(K=6)$. Each individual is represented by a single vertical line broken into six coloured segments, with lengths proportional to each of the $K$ inferred clusters. Abbreviation of the samples is provided in Table 1. Vertical black lines separate the populations. (PDF $1421 \mathrm{~kb}$ )

Additional file 2: Table S1. SNP properties, genome location, substitution type, $F_{\mathrm{ST}} P$-value associated with test for outlier status, minor allele frequency. (PDF $302 \mathrm{~kb}$ )

Additional file 3: Table S2. Allele frequencies of 53 SNP loci for 19 Mytilus spp. samples. (PDF $190 \mathrm{~kb}$ )

Additional file 4: Table S3. $F_{\text {ST }}$ distance matrix for 53 SNP, 19 samples of Mytilus mussels. (PDF $89 \mathrm{~kb}$ )

Additional file 5: Table S4. Result of population assignment algorithms GeneClass for 19 populations of mussels. (PDF 20 kb)

\section{Abbreviations}

mtDNA: Mitochondrial DNA; RFLPs: Restriction fragment length polymorphism; SNP: Single nucleotide polymorphism

\section{Acknowledgements}

The authors thank Anne Chenuil for providing samples from Kerguelen Islands. This research was funded in part by the 2011/01/B/NZ9/04352 NCN project to R.W. and statutory task IV.1 in the IOPAS.

\section{Authors' contributions}

RW conceived the project and obtained funding. RW, MZ and JPAG designed the study. All authors made arrangements for sampling. MZ carried out bioinformatics analyses. All authors participated in writing the article. All authors read and approved the final manuscript.

\section{Funding}

This research was funded in part by the 2011/01/B/NZ9/04352 NCN project to R.W. and statutory task IV.1 in the IOPAS.

\section{Availability of data and materials}

Data are presented in Supplementary material.

\section{Ethics approval and consent to participate}

Not applicable.

\section{Consent for publication}

Not applicable.

\section{Competing interests}

The authors declare that they have no competing interests.

\section{Author details}

${ }^{1}$ Institute of Oceanology, Polish Academy of Sciences, Powstańców Warszawy 55, 81-712 Sopot, Poland. ${ }^{2}$ School of Biological Sciences, Victoria University of Wellington, P O Box 600, Wellington 6140, New Zealand.
Received: 8 April 2019 Accepted: 24 July 2019

Published online: 06 August 2019

\section{References}

1. González-Wevar CA, Gérard K, Rosenfeld S, Saucède T, Naretto J, Díaz A, Morley SA, Brickle P, Poulin E. Cryptic speciation in Southern Ocean Aequiyoldia eightsii (Jay, 1839): Mio-Pliocene trans-Drake Passage separation and diversification. Prog Oceanogr. 2019;174:44-54.

2. Grosholz E. Ecological and evolutionary consequences of coastal invasions. Trends Ecol Evol. 2002;17:22-7.

3. Bax N, Williamson A, Aguero M, Gonzalez E, Geeves W. Marine invasive alien species: a threat to global biodiversity. Mar Policy. 2003;27:313-23.

4. Gardner JPA, Wenne R, Westfall KR, Zbawicka M. Invasive mussels threaten regional scale genetic diversity in mainland and remote offshore locations: the need for baseline data and enhanced protection in the Southern Ocean. Glob Change Biol. 2016;22:3182-95.

5. Hughes KA, Convey P, Pertierra LR, Vega GC, Aragónb P, Olalla-Tárraga MÁ. Human-mediated dispersal of terrestrial species between Antarctic biogeographic regions: a preliminary risk assessment. J Environ Manag. 2019;232:73-89.

6. Waters JM. Driven by the west wind drift? A synthesis of southern temperate marine biogeography, with new directions for dispersalism. J Biogeogr. 2008;35:417-27.

7. Fraser $\mathrm{Cl}$, Nikula $\mathrm{R}$, Waters JM. Oceanic rafting by a coastal community. P Roy Soc Lond B Bio. 2011;278:649-55.

8. Fraser $\mathrm{Cl}$, Morrison AK, Hogg AM, Macaya EC, van Sebille E, Ryan PG, Padovan A, Jack C, Valdivia N, Waters JM. Antarctica's ecological isolation will be broken by storm-driven dispersal and warming. Nat Clim Chang. 2018;8:704-8.

9. Gardner JPA. Hybridisation in the sea. Adv Mar Biol. 1997;31:1-78.

10. Brannock PM, Wethey DS, Hilbish TJ. Extensive hybridisation with minimal introgression in Mytilus galloprovincialis and M. trossulus in Hokkaido, Japan. Mar Ecol Prog Ser. 2009;383:161-71.

11. Fraïsse C, Belkhir K, Welch JJ, Bierne N. Local inter-species introgression is the main cause of outlying levels of intra-specific differentiation in mussels. Mol Ecol. 2016;25:269-86.

12. Hilbish TJ, Mullinax A, Dolven SI, Meyer A, Koehn RK, Rawson PD. Origin of the antitropical distribution pattern in marine mussels (Mytilus spp.): routes and timing of transequatorial migration. Mar Biol. 2000;136:69-77.

13. Larraín MA, Zbawicka M, Araneda C, Gardner JPA, Wenne R. Native and invasive taxa on the Pacific coast of South America: impacts on aquaculture, traceability and biodiversity of blue mussels (Mytilus spp.). Evol Appl. 2018;11:298-311.

14. Geller JB. Decline of a native mussel masked by sibling species invasion. Conserv Biol. 1999;13:661-4.

15. Elliott J, Holmes K, Chambers R, Leon K, Wimberger P. Differences in morphology and habitat use among the native mussel Mytilus trossulus, the non-native M. galloprovincialis, and their hybrids in Puget Sound, Washington. Mar Biol. 2008;156:39-53.

16. Saarman NP, Pogson $\mathrm{GH}$. Introgression between invasive and native blue mussels (genus Mytilus) in the central California hybrid zone. Mol Ecol. 2015:24:4723-38

17. Saarman NP, Kober KM, Simison WB, Pogson GH. Sequence-based analysis of thermal adaptation and protein energy landscapes in an invasive blue mussel (Mytilus galloprovincialis). Genome Biol Evol. 2017;9:2739-51.

18. Gérard K, Bierne N, Borsa P, Chenuil A, Féral J-P. Pleistocene separation of mitochondrial lineages of Mytilus spp. mussels from northern and southern hemispheres and strong genetic differentiation among southern populations. Mol Phylogenetics Evol. 2008;49:84-91.

19. Bayne BL. Responses to environmental stress: tolerance, resistance and adaptation. In: Gray JS, Christiansen ME, editors. Marine biology of polar regions and effects of stress on marine organisms. Chichester: Wiley; 1985. p. 331-49.

20. Crooks JA. Characterizing ecosystem-level consequences of biological invasions: the role of ecosystem engineers. Oikos. 2002;97:153-66.

21. Borthagaray Al, Carranza A. Mussels as ecosystem engineers: their contribution to species richness in a rocky littoral community. Acta Oecol. 2007;31:243-50.

22. GAA. Best aquaculture practices certification. Mussel farms. BAP standards, guidelines. Portsmouth: Global Aquaculture Alliance; 2013. p. 1-13. 
23. FAO. The State of World Fisheries and Aquaculture 2016. Contributing to food security and nutrition for all. Rome: FAO Fisheries and Aquaculture Department; 2016. p. 200. http://www.fao.org/3/a-i5798e.pdf.

24. Ferreira JG, Bricker SB. Goods and services of extensive aquaculture: shellfish culture and nutrient trading. Aquacult Int. 2016;24:803-25.

25. Ahmad M, Skibinski DOF, Beardmore JA. An estimate of the amount of genetic variation in the common mussel Mytilus edulis. Biochem Genet. 1977; 15:833-46

26. McDonald JH, Seed R, Koehn RK. Allozymes and morphometric characters of three species of Mytilus in the northern and southern hemispheres. Mar Biol. 1991;111:323-33.

27. Quesada H, Zapata C, Alvarez G. A multilocus allozyme discontinuity in the mussel Mytilus galloprovincialis: the interaction of ecological and life-history factors. Mar Ecol Prog Ser. 1995;116:99-116.

28. Cárcamo C, Comesaña ÁS, Winkler FM, Sanjuan A. Allozyme identification of mussels (Bivalvia: Mytilus) on the Pacific coast of South America. J Shellfish Res. 2005;24:1101-15.

29. Väinölä R, Strelkov P. Mytilus trossulus in northern Europe. Mar Biol. 2011;158:817-33.

30. Kartavtsev YP, Masalkova NA, Katolikova MV. Genetic and morphometric variability in settlements of two mussel species (Mytilus ex. gr. edulis), Mytilus trossulus and Mytilus galloprovincialis, in the Northwestern Sea of Japan. J Shellfish Res. 2018;37:103-19.

31. Edwards CA, Skibinski DOF. Genetic variation of mitochondrial DNA in mussel (Mytilus edulis and M. galloprovincialis) populations from south West England and South Wales. Mar Biol. 1987;94:547-56.

32. Blot $M$, Legendre $B$, Albert $P$. Restriction fragment length polymorphism of mitochondrial DNA in subantarctic mussels. J Exp Mar Biol Ecol. 1990;141:79-86.

33. Geller JB, Carlton JT, Powers DA. PCR-based detection of mtDNA haplotypes of native and invading mussels on the northeastern Pacific coast: latitudinal pattern of invasion. Mar Biol. 1994;119:243-9.

34. Quesada H, Gallagher C, Skibinski DAG, Skibinski DOF. Patterns of polymorphism and gene flow of gender-associated mitochondrial DNA lineages in European mussel populations. Mol Ecol. 1998;7:1041-51.

35. Zbawicka M, Wenne R, Skibinski DOF. Mitochondrial DNA variation in populations of the mussel Mytilus trossulus from the southern Baltic. Hydrobiologia. 2003;499:1-12.

36. Śmietanka B, Zbawicka M, Wołowicz M, Wenne R. Mitochondrial DNA lineages in the European populations of mussels (Mytilus spp.). Mar Biol. 2004;146:79-92.

37. Ort BS, Pogson GH. Molecular population genetics of the male and female mitochondrial DNA molecules of the California sea mussel, Mytilus californianus. Genetics. 2007;177:1087-99.

38. Rawson PD, Harper FM. Colonization of the northwest Atlantic by the blue mussel, Mytilus trossulus postdates the last glacial maximum. Mar Biol. 2009;156:1857-68

39. Li J, Ye Y, Wu C, Qi P, Guo B, Chen Y. Genetic variation of Mytilus coruscus Gould (Bivalvia: Mytilidae) populations in the East China Sea inferred from mtDNA COI gene sequence. Biochem Syst Ecol. 2013;50:30-8.

40. Śmietanka B, Zbawicka M, Sanko T, Wenne R, Burzynski A. Molecular population genetics of male and female mitochondrial genomes in subarctic Mytilus trossulus. Mar Biol. 2013;160:1709-21.

41. Zbawicka M, Wenne R, Burzynski A. Mitogenomics of recombinant mitochondrial genomes of Baltic Sea Mytilus mussels. Mol Gen Genomics. 2014;289:1275-87

42. Stewart DT, Sinclair-Waters M, Rice A, Bunker RA, Robicheau BM, Breton S. Distribution and frequency of mitochondrial DNA polymorphisms in blue mussel (Mytilus edulis) populations of southwestern Nova Scotia (Canada). Can J Zool. 2018;96:608-13.

43. Suchanek TH, Geller JB, Kreiser BR, Mitton JB. Zoogeographic distributions of the sibling species Mytilus galloprovincialis and M. trossulus (Bivalvia: Mytilidae) and their hybrids in the North Pacific. Biol Bull US. 1997;193:187-94.

44. Bierne N, Borsa P, Daguin C, Jollivet D, Viard F, Bonhomme F, David P. Introgression patterns in the mosaic hybrid zone between Mytilus edulis and M. galloprovincialis. Mol Ecol. 2003;12:447-61.

45. Hamer B, Korlević M, Durmiši E, Nerlović V, Bierne N. Nuclear marker Me 15/16 analyses of Mytilus galloprovincialis populations along the eastern Adriatic coast. Cah Biol Mar. 2012;53:35-44.

46. Lasota R, Piłczyńska J, Williams S, Wołowicz M. Fast and easy method for total DNA extraction and gene amplification from larvae, spat and adult mussels Mytilus trossulus from the Baltic Sea. Oceanol Hydrobiol St. 2013;42:486-9

47. Zardi Gl, McQuaid CD, Jacinto R, Lourenço CR, Serrão EA, Nicastro KR. Re-assessing the origins of the invasive mussel Mytilus galloprovincialis in southern Africa. Mar Freshwat Res. 2018;69:607-13.

48. Kijewski T, Zbawicka M, Strand J, Kautsky H, Kotta J, Rätsep M, Wenne R Random forest assessment of correlation between environmental factors and genetic differentiation of populations: case of marine mussels Mytilus. Oceanologia. 2019;61:131-42.

49. Presa P, Pérez M, Diz AP. Polymorphic microsatellite markers for blue mussels (Mytilus spp.). Conserv Genet. 2002;3:441-3.

50. Gardeström J, Pereyra RT, André C. Characterization of six microsatellite loci in the Baltic blue mussel Mytilus trossulus and cross-species amplification in North Sea Mytilus edulis. Conserv Genet. 2008;9:1003-5.

51. Lallias D, Stockdale R, Boudry P, Lapgue S, Beaumont AR. Characterization of ten microsatellite loci in the blue mussel Mytilus edulis. J Shellfish Res. 2009;28:547-51.

52. Venier $P$, De Pittà $C$, Bernante $F$, Varotto $L$, De Nardi B, Bovo G, Roch $P$, Novoa B, Figueras A, Pallavicini A, Lanfranchi G. MytiBase: a knowledgebase of mussel (M. galloprovincialis) transcribed sequences. BMC Genomics. 2009;10:72.

53. Xu TJ, Sun YN, Yuan YT, Liao Z, Wang RX. Isolation and characterization of polymorphic microsatellite loci in the hard-shelled mussel, Mytilus coruscus (Mytilidae). Genet Mol Res. 2010;9:1388-91.

54. Larraín MA, Díaz NF, Lamas C, Uribe C, Araneda C. Traceability of mussel (Mytilus chilensis) in southern Chile using microsatellite molecular markers and assignment algorithms. Exploratory survey. Food Res Int. 2014;62:104-10.

55. Araneda C, Noriega X, Jilberto F, Ruíz J, Jara C, Lafarga F, Larraín MA. Development of genome-wide microsatellite resources in a commercially important mussel species (Mytilus chilensis). Anim Genet. 2016;47:387-8.

56. Tanguy A, Bierne N, Saavedra C, Pina B, Bachère $E$, Kube M, Bazin E, Bonhomme F, Boudry P, Boulo V, Boutet I, Cancela L, Dossat C, Favrel P, Huvet $A$, Jarque $S$, Jollivet $D$, Klages $S$, Lapègue $S$, Leite $R$, Moal J, Moraga D, Reinhardt R, Samain JF, Zouros E, Canario A. Increasing genomic information in bivalves through new EST collections in four species: development of new genetic markers for environmental studies and genome evolution. Gene. 2008;408:27-36.

57. Vera M, Pardo BG, Pino-Querido A, Álvarez-Dios JA, Fuentes J, Martínez P. Characterization of single-nucleotide polymorphism markers in the Mediterranean mussel, Mytilus galloprovincialis. Aquac Res. 2010;41:e568-75.

58. Jilberto F, Araneda C, Larraín MA. High resolution melting analysis for identification of commercially-important Mytilus species. Food Chem. 2017;229:716-20.

59. Wenne R. Single nucleotide polymorphism markers with applications in aquaculture and assessment of its impact on natural populations. Aquat Living Resour. 2018;31:2.

60. Wilson J, Matejusova I, McIntosh RE, Carboni S, Bekaert M. New diagnostic SNP molecular markers for the Mytilus species complex. PLoS One. 2018:13:e0200654

61. Malachowicz M, Wenne R. Mantle transcriptome sequencing of Mytilus spp. and identification of putative biomineralization genes. PeerJ. 2019;6:e6245.

62. Zbawicka M, Drywa A, Smietanka B, Wenne R. Identification and validation of novel SNP markers in European populations of marine Mytilus mussels. Mar Biol. 2012;159:1347-62

63. Zbawicka M, Trucco MI, Wenne R. Single nucleotide polymorphisms in native south American Atlantic coast populations of smooth shelled mussels: hybridization with invasive European Mytilus galloprovincialis. Genet Sel Evol. 2018;50:5.

64. Reisser CMO, Bell JJ, Wood AR, Gardner JPA. Connectivity, small islands and large distances: the Cellana strigilis limpet complex in the Southern Ocean. Mol Ecol. 2011;20:3399-413.

65. Crandall ED, Treml E, Barber PH. Coalescent and biophysical models of stepping-stone gene flow in neritid snails. Mol Ecol. 2012;21:5579-98.

66. Pinheiro HT, Bernardi G, Simon T, Joyeux J-C, Macieira RM, Gasparini JL, Rocha C, Rocha LA. Island biogeography of marine organisms. Nature. 2017;549:82.

67. Gillespie RG, Baldwin BG, Waters JM, Fraser Cl, Nikula R, Roderick GK Long-distance dispersal: a framework for hypothesis testing. Trends Ecol Evol. 2011;27:47-56

68. Lee J, Chown SL. Mytilus on the move: transport of an invasive bivalve to the Antarctic. Mar Ecol Prog Ser. 2007;339:307-10.

69. Shaw JD, Terauds A, Riddle MJ, Possingham HP, Chown SL. Antarctica's protected areas are inadequate, unrepresentative, and at risk. PLoS Biol. 2014;12:e1001888 
70. Gérard K, Roby C, Bierne N, Borsa P, Féral J-P, Chenuil A. Does natural selection explain the fine scale genetic structure at the nuclear exon Glu-5 in blue mussels from Kerguelen? Ecol Evol. 2015;5:1456-73.

71. Hoarau G, Rijnsdorp AD, Van der Veer HW, Stam WT, Olsen JL. Population structure of plaice (Pleuronectes platessa L.) in northern Europe: microsatellites revealed large-scale spatial and temporal homogeneity. Mol Ecol. 2002;11:1165-76

72. Wenne R, Bach L, Zbawicka M, Strand J, McDonald JH. A first report on coexistence and hybridization of Mytilus trossulus and M. edulis mussels in Greenland. Polar Biol. 2016;39:343-55.

73. Gabriel S, Ziaugra L, Tabbaa D. SNP genotyping using the Sequenom MassARRAY iPLEX platform. Curr Protoc Hum Genet. 2009; Chapter 2:Unit 2.12.

74. Excoffier $L$, Lischer HEL. Arlequin suite version 3.5: a new series of programs to perform population genetics analyses under Linux and Windows. Mol Ecol Resour. 2010;10:564-7.

75. Benjamini $Y$, Yekutiel D. The control of the false discovery rate in multiple testing under dependency. Ann Stat. 2001;29:1165-88.

76. Narum SR. Beyond Bonferroni: less conservative analyses for conservation genetics. Conserv Genet. 2006;7:783-7.

77. Takezaki N, Nei M, Tamura K. POPTREEW: web version of POPTREE for constructing population trees from allele frequency data and computing some other quantities. Mol Biol Evol. 2014;31:1622-4.

78. Benzécri JP. Correspondence analysis handbook. In: Balakrishnan N, Schucany WR, Garvey PR, editors. Statistics: a series of textbooks and monographs. New York: Marcel Dekker Inc.; 1992.

79. Belkhir K, Borsa P, Chikhi L, Raufaste N, Bonhomme F. GENETIX version 4.04, logiciel sous Windows ${ }^{\mathrm{TM}}$ pour la génétique des populations. Montpellier: Laboratoire Génome, Populations, Interactions: CNRS UMR 5000, Université de Montpellier II; 2003.

80. Pritchard JK, Stephens M, Donnelly P. Inference of population structure using multilocus genotype data. Genetics. 2000;155:945-59.

81. Falush D, Stephens M, Pritchard JK. Inference of population structure using multilocus genotype data: dominant markers and null alleles. Mol Ecol Notes. 2007;7:574-8

82. Evanno G, Regnaut S, Goudet J. Detecting the number of clusters of individuals using the software STRUCTURE: a simulation study. Mol Ecol. 2005; 14:2611-20.

83. Lecis R, Pierpaoli M, Biro ZS, Szemethy L, Ragni B, Vercillo F, Randi E. Bayesian analyses of admixture in wild and domestic cats (Felis silvestris) using linked microsatellite loci. Mol Ecol. 2006:15:119-31.

84. Paetkau D, Calvert W, Stirling I, Strobeck C. Microsatellite analysis of population structure in Canadian polar bears. Mol Ecol. 1995;4:347-54

85. Rannala B, Mountain JL. Detecting immigration using multilocus genotypes. Proc Natl Acad Sci U S A. 1997:94:9197-202.

86. Piry S. GENECLASS2: a software for genetic assignment and first-generation migrant detection. J Hered. 2004;95:536-9.

87. Anderson EC, Thompson EA. A model-based method for identifying species hybrids using multilocus genetic data. Genetics. 2002;160:1217-29.

88. Lamy E. Révision des Mytilidae vivants du Museum national d'histoire naturelle de Paris. J Conch Paris. 1936;80:66-102, 107-198.

89. Daguin C, Borsa P. Genetic relationships of Mytilus galloprovincialis Lmk. populations worldwide: evidence from nuclear DNA markers. Geol Soc Spec Publ London. 2000;177:389-97.

90. Borsa P, Rolland V, Daguin-Thiébaut C. Genetics and taxonomy of Chilean smooth-shelled mussels, Mytilus spp. (Bivalvia: Mytilidae). C R Biol. 2012;335:51-61.

91. Lamarck JB. Histoire naturelle des animaux sans vertèbres présentant les caractères généraux et particuliers de ces animaux, leur distribution, leurs classes, leurs familles, leurs genres et la citation des principales espèces qui s'y rapportent, vol. 6. Paris: Librairie Verdière; 1819. p. 232.

92. Powell AWB. New Zealand molluscan systematics with descriptions of new species, part 3. Rec Auckland Inst Mus. 1958:5:87-91.

93. Westfall KM, Gardner JPA. Genetic diversity of southern hemisphere blue mussels (Bivalvia: Mytilidae) and the identification of non-indigenous taxa. Biol J Linn Soc. 2010;101:898-909.

94. Westfall KM, Gardner JPA. Interlineage Mytilus galloprovincialis Lmk. 1819 hybridization yields inconsistent genetic outcomes in the southern hemisphere. Biol Invasions. 2013;15:1493-506.
95. Hunt GL Jr, Drinkwater KF, Arrigo K, Berge J, Daly KL, Danielson S, Daase M, Hop H, Isla E, Karnovsky N, Laidre K, Mueter FJ, Murphy EJ, Renaud PE, Smith WO Jr, Trathan P, Turner J, Wolf-Gladrow D. Advection in polar and sub-polar environments: impacts on high latitude marine ecosystems. Prog Oceanogr. 2016;149:40-81.

96. Grant W, Cherry IM. Mytilus galloprovincialis Lmk. in southern Africa. J Exp Mar Biol Ecol. 1985;90:179-91.

97. Alexander ME, Simon CA, Griffiths CL, Peters K, Sibanda S, Miza S, Groenewald B, Majiedt P, Sink KJ, Robinson TB. Back to the future: reflections and directions of south African marine bioinvasion research. Afr J Mar Sci. 2016:38:141-4.

98. Briggs JC. Marine zoogeography. Series in Population Biology. New York: McGraw-Hill Book Co., Inc.; 1974. p. 475.

99. Bayne BL. Growth and the delay of metamorphosis of the larvae of Mytilus edulis (L.). Ophelia. 1965:2:1-47.

100. Miller JA, Carlton JT, Chapman JW, Geller JB, Ruiz GM. Transoceanic dispersal of the mussel Mytilus galloprovincialis on Japanese tsunami marine debris: An approach for evaluating rafting of a coastal species at sea. Mar Pollut Bull. 2018;132:60-9.

101. Longhurst AL. Ecological geography of the sea. San Diego: Academic; 1998. p. 398.

102. Oyarzún PA, Toro JE, Cañete Jl, Gardner JPA. Bioinvasion threatens the genetic integrity of native diversity and a natural hybrid zone: smoothshelled blue mussels (Mytilus spp.) in the Strait of Magellan. Biol J Linnean Soc. 2016;117:574-85.

103. Dueñas LF, Tracey DM, Crawford AJ, Wilke T, Alderslade P, Sánchez JA. The Antarctic circumpolar current as a diversification trigger for deep-sea octocorals. BMC Evol Biol. 2016;16:2.

104. Fraser Cl, Kay GM, du Pleiss M, Ryan PG. Breaking down the barrier: dispersal across the Antarctic polar front. Ecography. 2016;39:1-3.

105. Moon KL, Chown SL, Fraser Cl. Reconsidering connectivity in the sub-Antarctic Biol Rev. 2017;92:2164-81.

106. Zbawicka M, Sanko T, Strand J, Wenne R. New SNP markers reveal largely concordant clinal variation across the hybrid zone between Mytilus spp. in the Baltic Sea. Aquat Biol. 2014;21:25-36.

107. Larraín MA, Díaz NF, Lamas C, Vargas C, Araneda C. Genetic composition of Mytilus species in mussel populations from southern Chile. Lat Am J Aquat Res. 2012;40:1077-84.

108. Santaclara FJ, Espiñeira M, Cabado AG, Aldasoro A, Gonzalez-Lavín N, Vieites JM. Development of a method for the genetic identification of mussel species belonging to Mytilus, Perna, Aulacomya, and other genera. J Agr Food Chem. 2006:54:8461-70.

109. Gardner JPA, Westfall KM. Geographic distribution and molecular identification of a metapopulation of blue mussels (genus Mytilus) in northeastern New Zealand. J Mollus Stud. 2012;78:66-73.

110. Borsa P, Daguin C, Bierne N. Genomic reticulation indicates mixed ancestry in southern-hemisphere Mytilus spp. mussels. Biol J Linnean Soc. 2007;92:747-54

111. Colgan D, Middelfart P. Mytilus mitochondrial DNA haplotypes in southeastern Australia. Aquat Biol. 2011;12:47-53.

112. Dias PJ, Fotedar S, Snow M. Characterisation of mussel (Mytilus sp.) populations in Western Australia and evaluation of potential genetic impacts of mussel spat translocation from interstate. Mar Freshw Res. 2014;65:486-96

113. Ab Rahim ES, Nguyen TT, Ingram B, Riginos C, Weston KJ, Sherman CDH. Species composition and hybridisation of mussel species (Bivalvia: Mytilidae) in Australia. Mar Freshw Res. 2016:67:1955-63.

\section{Publisher's Note}

Springer Nature remains neutral with regard to jurisdictional claims in published maps and institutional affiliations. 